\title{
CHRONIC NON-HAEMOLYTIC JAUNDICE WITH CONJUGATED BILIRUBIN IN THE SERUM AND NORMAL LIVER HISTOLOGY: A CASE STUDY
}

\author{
BY \\ MARKUS F. VEST, HERBERT J. KAUFMANN and ELVIRA FRITZ \\ From the Children's Hospital, University of Basel, Basel, Switzerland
}

(RECEIVED FOR PUBLICATION MARCH 4, 1960)

\begin{abstract}
Recently our knowledge of bilirubin metabolism has increased considerably. Perhaps the most stimulating discovery has been that bilirubin is excreted in the bile as a glucuronide (Billing, Cole and Lathe, 1957; Schmid, 1957). This has made it possible to classify some rare types of chronic jaundice more definitely. One of these, chronic non-haemolytic familial jaundice, was described many years ago by Gilbert and Lereboullet (1901). Arias and London (1957) concluded from in vitro experiments with liver tissue that the cause of this disease was a defect in glucuronide formation. The inability to form glucuronides is also present in the much more severe type of inherited chronic jaundice with kernikterus described by Crigler and Najjar (1952) (cf. Axelrod, Schmid and Hammaker, 1957).
\end{abstract}

Neonatal jaundice also belongs to this group, characterized by insufficiency of glucuronyl-transferase in the liver (Dutton, 1959), but, in contrast to the diseases mentioned above, is a passing phenomenon, present only in the newborn period (Vest, 1958; Vest and Streiff, 1959).

There is another group of chronic non-obstructive, non-haemolytic jaundice in which no such defect in glucuronide formation is present. In consequence a substantial percentage of 'direct' reacting bile pigment is found in the serum, and bilirubin spills over into the urine. This group includes the form named chronic idiopathic jaundice (Dubin and Johnson, 1954), which is conspicuous by the presence of a pigment similar to lipofuscin in the liver cells (cf. Dubin, 1958). Clinical symptoms are fluctuating jaundice, episodes of abdominal pain, nausea, vomiting, enlarged liver and dark urine. Bromsulphalein retention is greatly increased.

A few reports have appeared on a syndrome similar to the Dubin-Johnson syndrome, where the characteristic pigment was missing on examination of the liver tissue (Rotor, Manahan and Florentin,
1948; Schiff, Billing and Oikawa, 1959; Haverback and Wirtschafter, 1960). There are some other small differences in symptomatology from the DubinJohnson syndrome. Most important of these are the absence of attacks of abdominal pain and the fact that the gall bladder can be easily seen on oral cholecystography. Only six patients with this syndrome have been described in the literature so far, to our knowledge. This makes it difficult to decide if the observed differences are constant features of this disturbance of bile pigment metabolism or if they are a variation of the pigmented type of chronic idiopathic jaundice.

The patient described here seems to belong to the non-pigmented group and is presented in the hope of further clarifying the picture of this pigmentless type of chronic non-haemolytic jaundice without insufficiency of glucuronide formation.

\section{Case Report}

W.M., a 7-year-old girl, born in 1952, is the only child of a family from southern Switzerland. The family history gives no indication of liver or blood disease; the pregnancy was normal and the child's birth weight was $3,270 \mathrm{~g}$. At the age of 4 weeks the mother observed a yellow tinge in the skin and this slightly icteric appearance has persisted. It is visible especially in the sclerae, but at times it increases in strength to an overt jaundice. When this happens the child is tired and anorrhexic, but there is no abdominal pain. Sometimes during these attacks the stools are paler than normal and the urine is dark. After a few days these symptoms subside. At the age of 13 months and 16 months the girl was seen by a paediatrician who found no abnormalities apart from icteric sclerae. Liver and spleen were not enlarged, $\mathrm{Hb}$ was $67 \%$ and $76 \%$ respectively. At the age of 28 months the patient was admitted to our hospital because of persistent jaundice.

First Admission. On admission skin and sclerae were icteric. The liver was palpable one finger-breadth below the costal margin; the spleen was not enlarged. 
Haematological studies showed no abnormalities with the exception of a slightly higher proportion of smaller cells than normal in the Price-Jones curve. Several times the fragility to hypotonic saline solutions was a little increased, total haemolysis occurring at from 0.49 to $0.51 \%$. These features were not persistent, however, and on other occasions normal values were observed. The direct Coombs test and indirect antiglobulin tests for antibodies were negative. Serum bilirubin level was high and varied between $7 \cdot 2$ and $4 \cdot 2 \mathrm{mg}$. \% with a moderate to strong direct van den Bergh reaction. Urobilinogen level in the urine was also high, but surprisingly no bilirubin could be detected in the urine with the method used at that time.

Extra-hepatic obstruction was thought unlikely from the benign course and from the normal aspect of the faeces. Also, on duodenal aspiration, normal enzyme activity (trypsin, diastase and lipase) was present in the duodenal secretion and $\mathrm{A}, \mathrm{B}$ and $\mathrm{C}$ bile of normal appearance and in normal amounts could be aspirated. Other laboratory findings are shown in Table 1.

Because of the slightly increased red cell fragility and spherocytosis a mild form of hereditary spherocytic anaemia was assumed at that time, despite the rather high bilirubin concentration in the serum and the fact that no abnormalities were found in the parents.

Second Admission. In 1959, at the age of $7 \frac{1}{2}$ years, the patient was readmitted for further studies because of her persistent slight jaundice with occasional exacerbation. On admission the height was $120 \mathrm{~cm}$. and body weight $23.7 \mathrm{~kg}$. There was a reddening of the throat and a throat culture produced haemolytic streptococci. The antistreptolysin titre was 1:320. Otherwise physical examination was negative, except for the icteric sclerae. Liver and spleen could be felt at the costal margin.

TABLE 1

LABORATORY FINDINGS

\begin{tabular}{|c|c|c|c|c|}
\hline \multicolumn{3}{|c|}{ Investigations } & 1955 & 1959 \\
\hline $\begin{array}{l}\text { Haemoglobin . . } \\
\text { Red cells millions/ms } \\
\text { Colour index .. } \\
\text { Anisocytosis . . } \\
\text { Leucocytes per mm.3 } \\
\text { Neutrophils stab } \\
\text { Neutrophils segmen } \\
\text { Neutrophils eosinor } \\
\text { Neutrophils basoph } \\
\text { Monocytes ... } \\
\text { Lymphocytes } \\
\text { Plasma cells... } \\
\text { Reticulocytes \% } \\
\text { Platelets } \\
\text { Haematocrit \% } \\
\text { Ratio of red cells to } \\
\text { in bone marrow } \\
\text { Price-Jones curve } \\
\text { Osmotic fragility: } \\
\text { beginning of haem } \\
\text { total haemolysis } \\
\text { Direct Coombs test } \\
\text { Indirect antiglobulin t } \\
\text { Auto-antibodies } \\
\text { Wassermann reaction } \\
\text { Prothrombin .. } \\
\text { Coagulation time } \\
\text { Bleeding time (sec.) }\end{array}$ & $\begin{array}{l}\text { m.3 } \\
\ldots \\
\ldots \\
\ldots \\
\text { nted } \\
\text { phil } \\
\text { iil } \\
\ldots \\
\ldots \\
\ldots \\
\ldots \\
\text { vhite cel } \\
\ldots \\
\ldots \\
\text { olysis } \\
\ldots \\
\text { test } \\
\ldots \\
\ldots \\
\ldots \\
\ldots\end{array}$ & $\begin{array}{l}\cdots \\
\cdots \\
\cdots \\
\cdots \\
\cdots \\
\cdots \\
\cdots \\
\cdots \\
\cdots \\
\cdots \\
\cdots \\
\ddot{11 s} \\
\cdots \\
\cdots \\
\cdots \\
\cdots \\
\therefore \\
\cdots \\
\cdots\end{array}$ & \begin{tabular}{|c|}
$87 \%$ \\
$4 \cdot 36$ \\
$1 \cdot 0$ \\
slight \\
7,300 \\
$7 \cdot 5$ \\
$22 \cdot 5$ \\
- \\
$12 \cdot 0$ \\
58 \\
$\overline{3} \cdot 5$ \\
286,000 \\
43 \\
$26 / 100$ \\
slight shift to left \\
0.45 to $0 \cdot 53 \%$ \\
$0 \cdot 39$ to $0 \cdot 41 \%$ \\
negative \\
negative \\
negative \\
negative \\
$80-100 \%$ \\
5 min. \\
45
\end{tabular} & $\begin{array}{c}90 \% \\
4 \cdot 26 \\
1 \cdot 07 \\
\text { slight } \\
9,150 \\
15 \cdot 5 \\
55 \\
0 \cdot 5 \\
\overline{5 \cdot 5} \\
23 \cdot 5 \\
0 \cdot 5 \\
1 \cdot 3 \\
81,000-160,000 \\
- \\
12 / 100 \\
\text { normal } \\
0 \cdot 49 \% \\
0 \cdot 35 \% \\
\text { negative }\end{array}$ \\
\hline
\end{tabular}

TABLE 2

LIVER FUNCTION TESTS

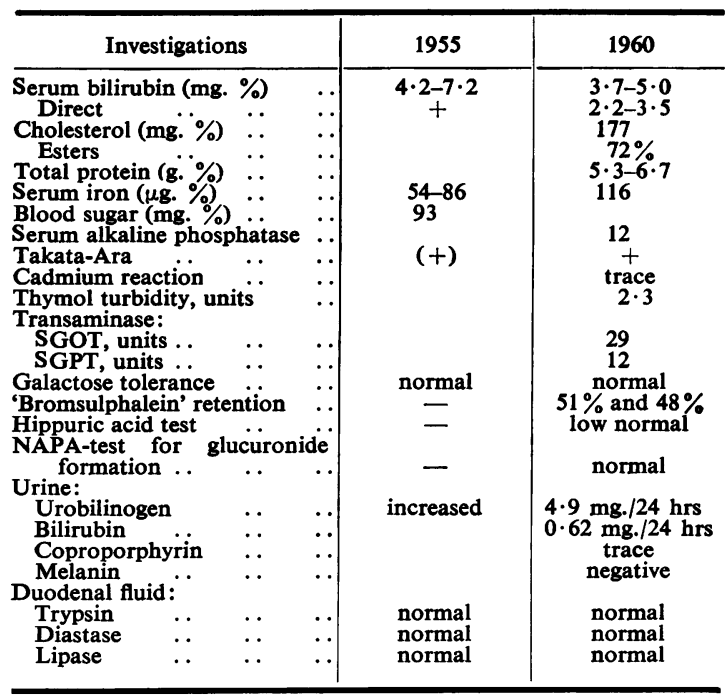

BLood Findings. The red cell count was $4 \cdot 26$ million, $\mathrm{Hb} 89 \%$ and colour index $1 \cdot 07$. Some anisocytosis was discernible. Reticulocytes $1 \cdot 3 \%$; white cell count 9,150 per c.mm. The differential count and additional haematological data are listed in Table 1.

Liver Function (Table 2). Takata-Ara reaction was one plus; cadmium, a trace; thymol-turbidity 2.3 units; total serum protein 5.35 and 6.7 g. \%. Paper electrophoresis revealed albumin $48 \%, \alpha_{1}$-globulin $5 \cdot 8 \%$, $\alpha_{2} 11 \cdot 6 \%, \beta 13.4 \%$, and $\gamma$-globulin $21 \cdot 2 \%$. The increase in $\gamma$-globulin was probably produced by the existing throat infection. Serum transaminase glutamic oxalacetic, 29 units; glutamic pyruvic, 12 units; serum alkaline phosphatase, 12 units; cholesterol, $177 \mathrm{mg}$. \%; cholesterol esters, $72 \%$. The prothrombin activity was $40 \%$ on admission, but afterwards, on repeated determinations, was always normal.

Serum bilirubin determination (methods of Jendrassik and Gróf, 1938; Malloy and Evelyn, 1937) gave values between 5.0 and $4.1 \mathrm{mg}$. \% for total bilirubin, the direct reacting pigment being 3.5 to $2.2 \mathrm{mg}$. \%. Paper chromatography of the serum by the method of Schmid (1957) showed two bands of azoderivatives with an $\mathrm{Rf}$ of 0.46 and 0.58 .

URINE. Urines generally were rather dark in colour. Urobilinogen excretion (average of two 24-hour collections) amounted to $4.86 \mathrm{mg}$. per day and therefore was greatly increased (method of Schwartz, Sborov and Watson, 1944). As expected from the increased amount of 'direct' reacting bile pigment in the serum, some bilirubin was excreted in the urine $(0.62 \mathrm{mg}$. per 24 hours) (method of With, 1942). Only a trace of porphyrin was found and a qualitative test for melanin was negative. Amino-nitrogen excretion was normal (31 mg. per 24 hours) and the amino-N-coefficient was 1.7. 
Stools. The stools were of normal colour. The faecal urobilinogen excretion (average of two 24-hour collections) was $32.25 \mathrm{mg}$. per day, a value that is normal for this age group (method used for estimation, Schwartz et al., 1944). The total bile pigment excretion (stools and urine) in 24 hours amounted to $37.1 \mathrm{mg}$. The haemolytic index (calculating a blood volume of $1,900 \mathrm{ml}$.) was 15 . This normal value excluded an accelerated red cell destruction. The ratio of faecal to urinary urobilinogen was very low, $6 \cdot 6: 1$ (the normal is about 100:1), showing that a much larger amount of urobilinogen was excreted by the kidneys than is normal.

'Bromsulphalein' Test. After intravenous injection of a dose of $5 \mathrm{mg}$. of 'bromsulphalein' (BSP) per $\mathrm{kg}$. body weight, the retention in the blood 30 minutes later was $51 \%$. On repetition of the test five weeks later, it was $48 \%$ (normal at this age $0-1 \cdot 5 \%$ ). The dye was detectable in the duodenal aspirate 45 minutes after the injection, whereas it normally appears within the first 15 minutes. The peak concentration of $66 \mathrm{mg}$. \% in the duodenal fluid was reached after 70 minutes and two hours after the injection the concentration was still higher than $50 \mathrm{mg}$. \%. Because of the difficulties in recording duodenal fluid volume it is not possible to give figures for absolute amounts excreted. In the urine $14.6 \%$ of the injected dose of BSP $(125 \mathrm{mg}$.) was excreted in the first two hours after administration; the following portions contained progressively smaller amounts, but even 18 hours later the BSP concentration was still $1.9 \mathrm{mg} . \%$. The results of the test are shown in Fig. 1. In addition chromatography of BSP metabolites in the serum 15, 30, 120 and 420 minutes after injection by the method of Carbone, Grodsky and Hjelte (1959) gave values of $5 \cdot 3 \%, 5 \cdot 4 \%, 17 \%$ and $26 \%$ respectively for BSP conjugates. This indicates an increase in the percentage of conjugated BSP concurring with a decrease in free BSP. In the bile, apart from free BSP, up to three BSP-conjugated were present, with $\mathrm{Rf}$-values of $0.64,0.57$ and 0.40 . From these findings an impairment of 'bromsulphalein' excretion is evident which seems to be caused not so much by a deficiency of conjugation as of secretion.

Hippuric ACID Test. After intravenous injection of $1.5 \mathrm{~g}$. benzoic acid the patient excreted $0.59 \mathrm{~g}$. hippuric acid in the urine within the following one-hour period. In our experience this can be considered as a low normal result in a child of this age. Glycine conjugating ability seems not to be impaired to a great extent.

GluCURONIDE Formation. N-acetyl-p-aminophenol (NAPA) was used as a substance to test the ability of the patient to form glucuronides. After oral or intravenous administration this substance is conjugated at the hydroxyl-group and excreted as glucuronide and sulphate in the urine. In adults the recovery within 24 hours is about 70 to $80 \%$ of the dose administered. Estimation of free NAPA in the serum and urine (Brodie and Axelrod, 1948) before and after hydrolysis with $\beta$-glucuroni-
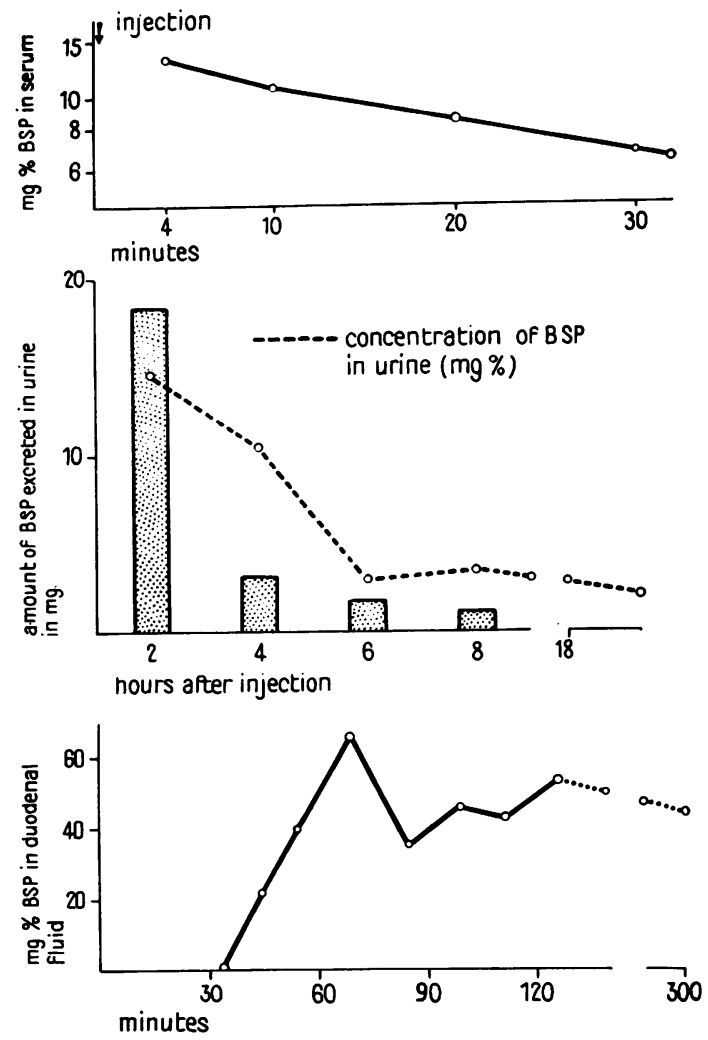

Fig. 1.-Bromsulphalein test; Upper part, concentration of 'bromsulphalein' in the serum after injection of BSP 5 mg. per kg. body weight, retention after 30 minutes, $51 \%$; Middle part, amount of BSP excreted in the urine in four two-hour periods and concentration of BSP in the urine at various intervals after injection; Lower part, time of appearance and concentration of BSP in the duodenal fluid.

dase makes it possible to calculate the amount of NAPA conjugated with glucuronic acid (Vest and Streiff, 1959). Fig. 2 shows the results obtained with this test after intravenous injection of $240 \mathrm{mg}$. of N-acetyl-p-aminophenol. Retention in the serum was $7 \cdot 6 \%$ after six hours (normal values are less than $10 \%$ ). The curve showing the concentration of NAPA-glucuronide at various time intervals also takes a normal course. The girl excreted in the urine $72.7 \%$ of the dose injected within 24 hours. Of this $10.8 \%$ was in the free form, $45 \%$ conjugated with glucuronic acid and the rest with sulphate. Fig. 2 also shows the increase of glucuronic acid in the serum, which occurred after administration of NAPA. On the other hand this load did not influence the level of the serum bilirubin. The excretion of glucuronic acid (estimated by the method of Dische, 1947) in the urine amounted to $57 \mathrm{mg}$. per 12 hours during a control period. After the injection of the NAPA it rose to $177 \mathrm{mg}$. in the first 12-hour period and to $107 \mathrm{mg}$. in the second. These findings show that glucuronide formation is not deficient in this patient. 

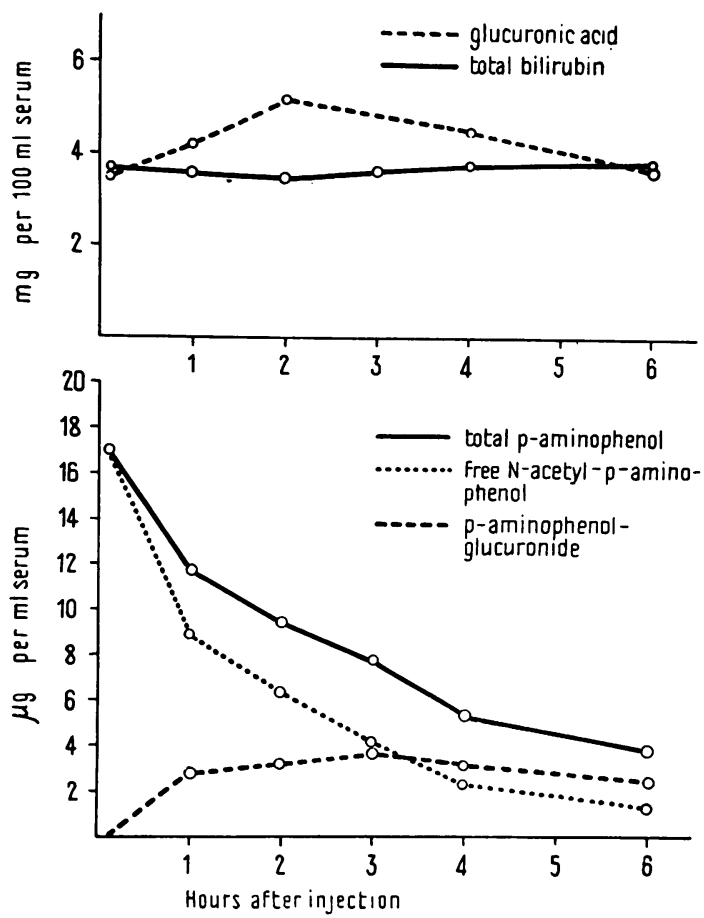

Fig. 2.-Test for the ability of the liver to form glucuronides; Upper part, concentration of glucuronic acid and total bilirubin in the serum at various times after injection of $\mathrm{N}$-acetyl-p-aminophenol in a dose of $10 \mathrm{mg}$. per kg. body weight; Lower part, concentration of total $\mathrm{p}$-aminophenol, free $\mathrm{N}$-acetyl-p-aminophenol and $\mathrm{p}$-aminophenol-glucuronide in the serum after the NAPA load.

RADIOGRAPHIC EXAMINATION. An oral cholecystography with four tablets of iopanoic acid (Cistobil 'Cilag') showed a well-filled gall bladder shadow. After ingestion of egg-yolk a contraction of the vesicle was clearly visible.

LIVER Biopsy. A liver biopsy was performed, using a Menghini needle (Menghini, 1958). Histological examination* revealed normal liver tissue with an unaltered lobular hepatic structure. There was no increase in connective tissue in the portal tracts. The small bile ductules were not dilated and there were no bile thrombi in the bile capillaries. Glycogen was present in the liver cells in normal amounts. No abnormal pigmentation was seen either in the liver or in the Kupffer cells.

\section{Discussion}

This patient presented the following symptoms: a chronic jaundice with a serum bilirubin level between 4 and $7 \mathrm{mg}$. \%, 50 to $70 \%$ of which reacted directly in the van den Bergh reaction; a normal

\footnotetext{
* Professor F. Roulet performed the examination of the liver biopsy specimen.
}

urobilinogen excretion in the stools but an increased amount of urinary urobilinogen and bilirubinuria; a markedly impaired BSP test, apparently without gross deficiency of conjugation; a low normal hippuric acid test; a normal glucuronide formation in a $\mathrm{N}$-acetyl-p-aminophenol loading test; no evident signs of hepatocellular damage (normal flocculation-tests, normal prothrombin, normal transaminase, etc.), and a liver biopsy showing no alterations.

The absence of anaemia and increased erythropoiesis, the normal amounts of urobilinogen in the stools and the considerable concentration of 'direct' bilirubin in the serum indicate that the icterus is not haemolytic in origin.

An incomplete biliary obstruction should lead to reduced faecal bile pigment. In addition, some signs of liver damage would be expected after an obstruction of this duration, but were not present in this patient. The results of the liver biopsy and the prompt filling of the gall bladder on cholecystography also rule out a biliary obstruction.

Constitutional hepatic dysfunction (Gilbert's disease) can be excluded on the basis of normal glucuronide formation, the occurrence of direct bilirubin in the serum, the bilirubinuria and the abnormal BSP retention.

The case can be differentiated from chronic idiopathic jaundice (Dubin-Johnson; black liver jaundice) by the absence of the characteristic pigment in the liver cells and the filling of the gall bladder on oral cholecystography. The symptom of abdominal pain, so commonly found in the Dubin-Johnson disease, was also missing. It seems likely therefore that this girl belongs to the group of patients with non-haemolytic jaundice with conjugated bilirubin in the serum, first described by Rotor et al. (1948), where no pigmentation is present in the liver cells.

In contrast to the observations of Schiff et al. (1959) urinary urobilinogen excretion was increased in this patient. This corroborates Haverback and Wirtschafter (1960) who found high urinary urobilinogen levels in their two patients. Increased values of urinary bile pigment have also been found in chronic idiopathic jaundice with liver cell pigmentation (Dubin, 1958).

There is also some discrepancy with the findings of Schiff et al. (1959) with regard to the percentage of 'bromsulphalein' conjugates in the serum after BSP injection. They report $6 \%$ and $4 \%$ respectively at 45 and 90 minutes and we found $5.3 \%$ at 15 minutes, $5 \cdot 4 \%$ at $30,17 \%$ at 120 and $26 \%$ at 420 minutes. From this it would seem that the percentage of conjugates increases with time. 
Perhaps, as with bilirubin, there is no deficiency of 'bromsulphalein' conjugation but mainly of secretion and this leads to the diminished removal rate from the plasma.

Nothing is known about the nature of the defect in this syndrome. Because an insufficiency of bilirubin glucuronide formation has been ruled out by all investigators, an impairment in the hepatic excretion of bilirubin glucuronide and a diminished uptake of bilirubin by the hepatic cells has been postulated (Schiff et al., 1959). The familial occurrence makes it possible that the defect is a genetic error of metabolism. Males and females can be affected. The condition seems to be compatible with normal life as evidenced by the stationary state of health of Rotor's original patients (Rotor, 1960) more than 12 years after their initial examination.

\section{Summary}

A case of non-haemolytic, chronic jaundice in a girl, 7 years of age, is presented. The pertinent findings were onset of jaundice at 4 weeks of age, serum bilirubin levels between 4 and $7 \mathrm{mg}$. \%, 50 to $70 \%$ of which gave a direct reaction, normal urobilinogen excretion in the stools, but increased urinary urobilinogen and bilirubinuria, 'bromsulphalein' retention of $50 \%$ after 30 minutes and low normal hippuric acid formation. The ability to conjugate with glucuronic acid in a $\mathrm{N}$-acetyl-paminophenol loading test was normal. Oral cholecystography revealed a normal gall bladder. Other liver function tests were essentially normal. Liver biopsy showed a regular structure and appearance of the liver tissue without pigmentation. Chronic idiopathic jaundice (Dubin-Johnson syndrome) could therefore be ruled out and the patient was classified as a case of jaundice of the type described by Rotor et al. (1948).

\section{REFERENCES}

Arras, I. M. and London, I. M. (1957). Bilirubin glucuronide formation in vitro; demonstration of a defect in Gilbert's disease. Science, 126, 563 .

Axelrod, J., Schmid, R. and Hammaker, L. (1957). A biochemical lesion in congenital non-obstructive, non-haemolytic jaundice. Nature (Lond.), $180,1426$.

Billing, B. H., Cole, P. G. and Lathe, G. H. (1957). The excretion of bilirubin as a diglucuronide giving the direct van den Bergh reaction. Biochem, $J, 65,774$.

Brodie, B. B. and Axelrod, J. (1948) The estimation of acetanilide and its metabolic products, anilide, $\mathrm{N}$-acetyl p-aminophenol and p-aminophenol (free and total conjugated) in biological fluids and tissues. J. Pharmacol. exp. Ther., 94, 22.

Carbone, J. V., Grodsky, G. M. and Hjelte, V. (1959). Effect of hepatic dysfunction on circulating levels of sulfobromophthalein and its metabolites. J. clin. Invest., 38, 1989.

Crigler, J. F. and Najjar, V. A. (1952). Congenital familial nonhemolytic jaundice with kernicterus. Pediatrics, 10, 169.

Dische, Z. (1947). A new specific color reaction of hexuronic acids. J. biol. Chem., 167, 189.

Dubin, I. N. (1958). Chronic idiopathic jaundice. A review of fifty cases. Amer. J. Med., 24, 268.

- and Johnson, F. B. (1954). Chronic idiopathic jaundice with unidentified pigment in liver cells; a new clinicopathologic entity with a report of 12 cases. Medicine (Baltimore), 33, 155 .

Dutton, G. J. (1959). Glucuronide synthesis in foetal liver and other tissues. Biochem. J., 71, 141

Gilbert, A. and Lereboullet, P. (1901). La cholémie simple familiale. Sem. méd. (Paris), 21, 241.

Haverback, B. J. and Wirtschafter, S. K. (1960). Familial nonhemolytic jaundice with normal liver histology and conjugated bilirubin. New Engl. J. Med., 262, 113.

Jendrassik, L. and Gróf, P. (1938). Vereinfachte photometrische Methoden zur Bestimmung des Blutbilirubins. Biochem. Z., 297, 81 .

Malloy, H. T. and Evelyn, K. A. (1937). The determination of bilirubin with the photoelectric colorimeter. J. biol. Chem., 119,481 .

Menghini, G. (1958). One-second needle biopsy of the liver. Gastroenterology, 35, 190.

Rotor, A. B. (1960). Personal communication.

Manahan, L. and Florentin, A. (1948). Familial nonhemolytic jaundice with direct van den Bergh reaction. Acta med. philipp., 5, No. 2 (Oct.-Dec.), 37.

Schiff, L., Billing, B. H. and Oikawa, Y. (1959). Familial nonhemolytic jaundice with conjugated bilirubin in the serum. New Engl. J. Med., 260, 1315.

Schmid, R. (1957). The identification of 'direct-reacting' bilirubin as bilirubin glucuronide. $J$. biol. Chem., 229, 881.

Schwartz, S., Sborov, V. and Watson, C. J. (1944). Studies of urobilinogen. IV. The quantitative determination of urobilinogen by means of the Evelyn photoelectric colorimeter. bilinogen by means of the

Vest, M. (1958). Insufficient glucuronide formation in the newborn and its relationship to the pathogenesis of icterus neonatorum. Arch. Dis. Childh., 33, 473 .

- and Streiff, R. R. (1959). Studies on glucuronide formation in newborn infants and older children. A.M.A. J. Dis. Child., 98, 688.

With, T. K. (1942). Ueber die quantitative Bestimmung von Bilirubin in Harn und Stuhl. Hoppe-Seylers Z. physiol. Chem., $275,166$. 